\title{
A Review on Effect of INM on Sugarcane Growth, Yield and Quality
}

\author{
Abhishek Ranjan ${ }^{1 *}$, C. K. Jha ${ }^{2}$ and Navnit Kumar ${ }^{3}$ \\ ${ }^{1}$ Department of Soil Science, CPGS-AS (CAU, Imphal), Umiam-793103, India \\ ${ }^{2}$ Department of Soil Science, SRI, RPCAU, Pusa (Samastipur), Bihar-848125, India \\ ${ }^{3}$ Department of Agronomy, SRI, RPCAU, Pusa (Samastipur), Bihar-848125, India \\ *Corresponding author
}

\section{A B S T R A C T}

\section{Keywords}

IMN, Sugarcane,

Biomethanated distellury effluent,

Biogas slurry,

Biocompost and

biofertilizers, Yield

Article Info

Accepted:

25 December 2019

Available Online:

20 January 2020
Integrated nutrient management programme is unavoidable for achieving sustainable sugarcane production along with quality of sugarcane. Application of organic nutrient sources viz., farmyard manure, cane trash, pressmud, vermicompost. biomethanated distillery effluent, biogas slurry, biocompost and biofertilizers along with inorganic sources of nutrients in combination have recorded increased cane yield over only inorganic fertilizer application, in addition to improvement in soil fertility and reducing the cost of cane production. Intercropping and incorporation of green manures have established beneficial effects in improving sugarcane productivity in conjunction with higher nutrient use efficiency. Nitrogen fixing biofertilizers' are useful in economizing the increment in cane yield. Integration of organics and inorganics in 1:1 ratio leads to saving of $50 \%$ inorganics and increase in yield upto $21 \%$.

\section{Introduction}

Sugarcane (Saccharum spp. complex hybrid) is an important cash crop of India. Sugar industry is the $2^{\text {nd }}$ largest agro-based industry in India and contributes significantly to the socio-economic development of the nation. Indian sugar industry is also a major sector to create employment, probably $7.5 \%$ per cent in Indian economy and plays a leading role in global market being the world's $2^{\text {nd }}$ largest producer after Brazil, producing nearly 15 and $25 \%$ of global sugar and sugarcane respectively. Sugar industry is the source of livelihood for 50 million farmers and their families. It provides direct employment to over 5 lakh skilled and semi-skilled labours in sugar mills and allied industries across the nation (Venkatesh and Venkateswarlu, 2017).

The economic part of sugarcane is the stalk where sucrose is accumulated from which sugar is prepared. Sugarcane crop and its products contribute about $1.1 \%$ to the national GDP which is significant considering that the crop is grown only in 3\% of the gross cropped area. The contribution of sugarcane to the agricultural GDP has steadily increased from 
about $5 \%$ in $1990-1991$ to $10 \%$ in 2010 2011. During the last two decades, the average annual growth of sugarcane agriculture sector was about $2.6 \%$ as against overall growth of $3 \%$ in agriculture sector in the country (Solomon, 2015).

With per capita consumption of white sugar at $22 \mathrm{~kg}$ annum $^{-1}$, and the estimated population of 1.50 billion by 2030 AD., the consumption of white sugar may be increased to 33 million tonnes. It is estimated that by 2030 AD., about 520 million tonnes of sugarcane with average sugar recovery of 10.75 per cent $(60$ per cent cane will be utilized for white sugar, and 15 per cent will go for ethanol production) will be required. This will entail a productivity requirement of 100-110 $\mathrm{t} \mathrm{ha}^{-1}$, since the area under sugarcane cultivation may stabilize around 5.00 mha (IISR, 2011).

The exploding population and its demand for food, fiber and energy which is increasing every year needs to be fulfilled sustainably. This can be achieved only by increasing the vertical productivity of plants in consideration, since the area cannot be increased. This increase in production not only calls for management of plants but also the soil since the soil is losing its fertility day by day. Therefore a holistic approach is required to not only increase the yield per hectare of plants but also to maintain the deteriorating soil health. The options available to us are not limited but we need to use it judiciously. Organic manures apart from acting as a source of nutrients also improve soil health by improving the soil biodiversity, microbial population as well as improvement of soil physical and chemical property. Use of organic manure either singly or in combination with chemical fertilizers will sustain the soil fertility or improve the soil health.

The unsustainability of Chemical-driven agricultural practices have led decline in the crop productivity as well as hamper the soil fertility. This necessitates the use of alternative sources of plant nutrients which not only improves soil health but can also improve and sustain productivity of sugarcane. Majority of these sources are easily accessible to the farmers and therefore also reduces the cost of cultivation thereby improving the income level of farmers. Use of organic sources of nutrients either alone or in combination with chemical fertilizer pertains to eco-friendly practices which lead to a holistic management of soil-crop system. The alternative to chemical driven farming is organic farming which promotes and improves the health of agro ecosystem related to biodiversity, nutrient biocycles, soil microbial and bio-chemical activities (Chogatapur et al., 2017). Organic farming emphasizes largely on use of different organic manures (bulky and concentrated) along with practices such as green manuring, use of biofertilizers and biopesticides. It also emphasizes on use of various cultural practices along with botanicals for managing pest and diseases.

The practice of organic farming depends upon the nature and source of plant nutrients, understanding the practices which are situation specific. India ranks $9^{\text {th }}$ in terms of land under organic cultivation and $1^{\text {st }}$ in terms of total number of organic producers (IFOAM Year Book, 2018). In India, the total area under organic farming is 3.56 mha from which $1.70 \mathrm{mMT}$ of certified organic products were produced including all varieties of food products viz., oilseeds, sugarcane, cereals and millets, cotton, pulses, medicinal plants, tea, fruits, vegetables etc. The export of organic products also earns handsome revenue to the state. The organic food export realization for 2017-18 was around INR 3453.48 crore (Apeda, 2018). 
Nutrient Management and its effect on Sugarcane

A cane yield of $100 \mathrm{t} \mathrm{ha}^{-1}$ may remove $205 \mathrm{~kg}$ $\mathrm{N}, 55 \mathrm{~kg} \mathrm{P}, 275 \mathrm{~kg} \mathrm{~K}, 30 \mathrm{~kg} \mathrm{~S}, 3.5 \mathrm{~kg} \mathrm{Fe}, 1.2$ $\mathrm{kg} \mathrm{Mn}, 0.6 \mathrm{~kg} \mathrm{Zn}$ and $0.2 \mathrm{~kg} \mathrm{Cu}$ from the soil besides the losses of nutrients during cropping season (Kumar and Chand, 2009). This necessitates the use of organic manures, which is a reservoir of nutrients (macro and micro) for improving the sustainable productivity of sugarcane. Various organic sources of plant nutrients like farmyard manure (FYM), oil cakes, press mud cake, vermicompost, green manure, legume as intercrops and sugarcane trash are being explored for use as sources of nutrients since ages. Addition of organic amendments represents an important strategy to protect agricultural lands from excessive soil resource exploitation and to maintain soil fertility.

India being the largest sugarcane cultivar in world generates huge amount of wastes as by product of cane plantation as well as sugar production. Recycling of sugar industry wastes can be gainfully utilized to enhance sugar productivity and reduce the cost of cane production.

Organic sources of nutrients not only help in supplementing the nutrients to sugarcane but also maintain favorable physical, chemical and biological soil environment. Long term fertilizer experiments have indicated the need for basal application of FYM for maintaining optimum fertility status. Sugarcane trash is the chiefly available organic waste in cane growing areas accounting for $10-12 \%$ of the cane weight. Press mud and distillery effluent being an important waste material of sugar industry can be used as such or as biocompost after their decomposition with the help of microbes. The works of different people throughout the world on organic sources of nutrients concludes that it not only supplies plant nutrients throughout the growing phase of sugarcane but also improves the physical, chemical and biological characteristics of soil. The use of bio-fertilizer in addition to organic manures improves the availability of nutrients in soil determining the growth and yield of crop. Also, the incorporation of organic materials along with fertilizer-N affects the amount and distribution of organic $\mathrm{N}$-fraction viz. exchangeable $\mathrm{NH}_{4}{ }^{+}-\mathrm{N}$, hydrolysable $\mathrm{NH}_{4}{ }^{+} \mathrm{N}$, hexoseamine- $\mathrm{N}$, amino acid- $\mathrm{N}$, unidentified-N and status of total-N (Santhy et al., 1998) and carbon pool considerably in soil (Sinha et al., 2017).

\section{Effect of organic manures on growth and yield attributing characters of sugarcane}

Kathiresan et al., (1993) observed significantly higher number of shoots with the combined application of neem coated urea $\left(210 \mathrm{~kg} \mathrm{~N} \mathrm{ha}{ }^{-1}\right)$, press mud $\left(25 \mathrm{t} \mathrm{ha}^{-1}\right)$ and phosphobacteria $\left(10 \mathrm{~kg} \mathrm{ha}^{-1}\right)+$ Azospirillium $\left(10 \mathrm{~kg} \mathrm{ha}^{-1}\right)$. Navale et al., (1995) reported significant improvement in germination, tillering, number of millable canes, and girth and height of cane in Azospirillum + Azotobacter treatment with fertilizer $\mathrm{N}$ along with saving of $25-50 \mathrm{~kg} \mathrm{ha}^{-1}$ fertilizer-N. Among the green manures incorporated, Crotolaria juncea recorded highest number of millable canes followed by Sesbania aculeata (Kathiresan and Manoharan, 1999). Roodagi et al., (2000) reported maximum tiller count with sugarcane + sunnhemp (as green manure crop) compared to sugarcane sole crop. Shankaraiah et al., (2001) carried out research at Mandya, Karnataka and reported that application of SSP and press mud on equal P basis along with phosphate solubilizing bacteria improved leaf area index (LAI), length and weight of stalk. Patel (2002) revealed that application of trash mulch (@ $10 \mathrm{tha}^{-1}$ ) and FYM (@25 tha ${ }^{-1}$ ) significantly improved single cane weight which is directly related to cane yield. Sharma et al., (2005) reported that integration of FYM with fertilizers in 1:1 ratio was found better with respect to increased shoot population due to 
blending of organic and inorganic nutrient sources in equal ratio (50:50) leading to saving of $50 \%$ inorganics. Inoculation of sugarcane with Gluconacetobacter diazotrophicus improved germination, plant population and plant height due to release of growth promoting substances in addition to increased uptake of nutrients (Suman et al., 2005). Singh et al., (2007) recorded highest number of millable canes, longest and thickest canes with addition of press mud (@ $10 \mathrm{t} \mathrm{ha}$ $\left.{ }^{1}\right)$.

The integrated application of by nutrients with 75 per cent recommended inorganics + pressmud (@20 t ha ${ }^{-1}$ ) + rice mill husk (@ $10 \mathrm{t} \mathrm{ha}^{-1}$ ) gave higher number of millable canes, cane height and girth (Paul and Mannan, 2007). Yadahalli (2008) found that application of neem cake helped for significantly higher germination percentage $(68.5 \%)$ than other amendments. There was a significant improvement in number, length and girth of millable canes, number of nodes and length of internodes with the combination of organic and inorganic plant nutrient sources along with biofertilizers as reported by Kanjana and Pitchai (2009). Jamuna and Paneerselvam (2014) found maximum millable cane population with the application of Gluconacetobacter diazotrophicus (@10 $\mathrm{kg} \mathrm{ha}{ }^{-1}$ ) + AM fungi (@25 kg ha ${ }^{-1}$ ) + Azophos (@ $10 \mathrm{~kg} \mathrm{ha}^{-1}$ ) +75 per cent RDF. Integration of press mud, sugarcane trash and micronutrient $\mathrm{Fe}$ recorded significantly higher number of tillers, and number, length and weight of millable canes over RDF (Jha et al., 2017). Umesh et al., (2018) concluded that number of tillers and millable canes increased significantly at higher level of $\mathrm{N}$ when applied with organic manure whereas the effect of biogas slurry was found more pronounced.

\section{Effect of organic manures on yield of sugarcane}

Sonawane and Sabale (2000) found higher cane and sugar yield on application of $250 \mathrm{~kg}$ nitrogen through urea and $50 \mathrm{~kg} \mathrm{~N}$ through press mud showed positive response with respect to cane yield and trash yield. Shankaraiah and Hunsigi (2000) reported that soil inoculation of nitrogen fixers viz., Azotobacter in plant crop and Azospirillum in ratoon crop increased cane yield by $10-15 \%$ and Agrobacterium radiobacter and Bacillus megaterium in plant crop and Aspergillus awamori and Bacillus megaterium in ratoon crop exhibited 8-10 per cent higher cane yield as a result of perceptible improvement in various growth and yield parameters. Bokhtiar et al., (2001) observed 20-30 per cent in plot receiving press mud (@20 t ha-1) along with fertilizer $\mathrm{N}$ over RDF. Inoculation of combined culture of Azotobacter + Azospirillum or Acetobacter + P-solubilizing bacteria with 75 per cent of $\mathrm{N}$ and $\mathrm{P}$ along with full dose of $\mathrm{K}$ gave 30 per cent higher cane yield than uninoculated control as observed by Lokhande and Ghatge (2001). Manickam et al., (2002) reported higher cane and sugar yield in plots receiving 100 per cent NPK + sunnhemp over RDF. Shankaraiah and Nagaraju (2002) established that soil inoculation with Azotobacter chrococcum and Azospirillumbrasiliense (@2.5 kg ha ${ }^{-1}$ each) gave higher jiggery yield in both plant and ratoon crop. Durai and Devaraj (2003) reported higher cane and sugar yield with application of FYM $+100 \%$ NPK + Azospirillum whereas Kathiresan (2004) reported higher cane and sugar yield with application of $75 \% \mathrm{RDN}+$ soil inoculation of Azospirillum and Azotobacter. Integrated use of enriched press mud (@15 t ha ${ }^{-1}$ ) at recommended fertilization resulted in increased cane and sugar yield to the tune of 21 per cent over RDF (Shankaraiah and Kalyanmurthy, 2005). Hari and Srinivasan (2005) observed that Azospirillum under lower nitrogen level significantly improved cane and sugar yield over Gluconacetobacter, Azotobacter and uninoculated control. Saini et 
al., (2006) reported that press mud cake (@ $\left.10 \mathrm{t} \mathrm{ha}^{-1}\right)+$ fly ash $\left(@ 10 \mathrm{t} \mathrm{ha}^{-1}\right)+$ PSB along with 75 per cent RDF significantly improved cane and sugar yield over chemical fertilizers alone. Chauhan et al., (2008) observed that highest cane yield was achieved in the treatment receiving $\mathrm{N}$ through bio-compost and inorganic source (50:50) on equal $\mathrm{N}$ basis followed by 33 per cent $\mathrm{N}$ through biocompost +67 per cent through inorganic fertilizer. Srivastava et al., (2008) reported highest cane yield with sulphitation press mud (@10 t ha ${ }^{-1}$ ) + FYM (@10 t ha ${ }^{-1}$ ) in autumn and spring planted sugarcane crop. Trash burning along with incorporation of Sesbania aculeata gave 50.6 and 17.7 per cent increase in ratoon cane yield over trash removal and trash burning treatments respectively (Chandra et al., 2008). Integration of FYM at 25 per cent RDN with fertilizers and biofertilizers to plant crop and trash incorporation (@10 t ha ${ }^{-1}$ ) to ratoon crop increased cane yield (Virdia et al., 2009). Rani et al., (2011) revealed that 50 per cent reduction of inorganic fertilizer with oil cakes in plant cane and addition of 50 per cent more $\mathrm{N}$ with same amount of fertilizer for ratoon crop improved cane and sugar yield. FYM + RDF registered higher cane yield over only RDF as elucidated by Lakshmi et al., (2011). Singh et al., (2014) established that cane yield increased significantly due to integrated use of inorganic + organic fertilizer along with dual biofertilizers (Azotobacter + PSB).

Table.1 Effect of different organic manures on productivity of sugarcane

\begin{tabular}{|c|c|c|c|c|c|}
\hline \multirow[t]{3}{*}{ Organic manures } & \multicolumn{4}{|c|}{ Cane yield $\left(\mathrm{t} \mathrm{ha}^{-1}\right)$} & \multirow[t]{3}{*}{ References } \\
\hline & \multirow{2}{*}{$\begin{array}{l}\text { Without } \\
\text { organic } \\
\text { manures }\end{array}$} & \multirow{2}{*}{$\begin{array}{l}\text { With organic } \\
\text { manures }\end{array}$} & \multicolumn{2}{|c|}{ Increase / decrease } & \\
\hline & & & $\left(\mathrm{t} \mathrm{ha}^{-1}\right)$ & $(\%)$ & \\
\hline Sesbania aculeate & 104.9 & 144.5 & 39.6 & 37.75 & Chandra et al., 2008 \\
\hline Vermicompost & 87.42 & 93.88 & 6.46 & 7.38 & Lakshmi et al., 2011 \\
\hline Sugarcane trash & 47.0 & 59.3 & 12.3 & 26.17 & Umesh et al., 2013 \\
\hline $\begin{array}{c}\text { Biomethanated } \\
\text { distillery effluent }\end{array}$ & 58.50 & 72.13 & 13.63 & 23.29 & Sinha et al., 2014 \\
\hline Biocompost & 58.70 & 74.14 & 15.44 & 26.30 & Sinha et al., 2017 \\
\hline Biogas slurry & 57.0 & 70.2 & 13.2 & 23.15 & Umesh et al., 2018 \\
\hline
\end{tabular}

Cane yield increased significantly with the application of BMDE, bio-compost and FYM over control (Sinha et al., 2014). Bhanuvally et al., (2017) concluded that application of 125 per cent $\mathrm{N}$ through either neem or sulphur or coal tar coated urea improved cane yield significantly by increasing nitrogen use efficiency and by reducing the nitrogen losses. Srivastava et al., (2018) observed increase in ratoon crop yield from fifth to ninth ratoon crop due to addition of biomanures over RDF.

\section{Effect of organic manures on quality of sugarcane}

Sonawane and Sabale (2000) reported that application of $250 \mathrm{~kg}$ nitrogen through urea and $50 \mathrm{~kg} \mathrm{~N}$ through press mud showed positive response with respect to brix, pol, CCS per cent and sugar yield. Shankaraiah and Nagaraju (2002) revealed that soil inoculation of Azospirillum brasilense @ 2.5 $\mathrm{kg} \mathrm{ha}^{-1}$ resulted in improvement of the sucrose content in jaggery with parallel reduction in the level of reducing sugar both in plant and 
ratoon crop. Jeyaramana and Alagudurai (2003) found that application of 275:62.5:112.5 kg N, $\mathrm{P}_{2} \mathrm{O}_{5}$ and $\mathrm{K}_{2} \mathrm{O}$ per hectare with daincha as an intercrop and its incorporation at 60 days after planting along with soil application of phosphobacteria (@ $10 \mathrm{~kg} \mathrm{ha}^{-1}$ ) at the time of planting setts recorded higher brix, pol, purity and CCS in sugarcane juice. Application of PMC (@10 t $\mathrm{ha}^{-1}$ ) coupled with biofertilizers (PSB) at 2.5 $\mathrm{kg}$ improved the quality of sugarcane compared to recommended NPK aone observed by Saini et al., (2006).

Venkatakrishnan and Ravichandran (2007) reported that application of press mud significantly improved juice quality of sugarcane with higher value of brix and pol percentage in plots treated with press mud @ $25 \mathrm{t} \mathrm{ha}^{-1}$. Vedprakash et al., (2009) observed that application of FYM, ground nut cake and inorganic nitrogen in the ratio of 1:1:1 proved better with regards to cane yield but without alteration in juice quality.

Thakur et al., (2012) reported that cane juice quality viz., brix, sucrose and purity content remains unaffected under organic and conventional farming system. Sinha et al., (2014) revealed that the quality of juice, viz., sucrose and purity remains unaffected due to INM. Kumar et al., (2015) observed trash mulching@10 tha ${ }^{-1}$ significantly improved brix, pol and $\mathrm{CCS} \%$ of cane juice over control. Umesh et al., (2018) established that the juice quality significantly enhanced at higher $\mathrm{N}$ level in conjoint with BGS.

Conclusion of the study is as follows:

In order to maintain the sugarcane productivity of sugarcane at a higher level on a long-term basis it is indispensable to evolve a system whereby integration of nutrients from all the available sources should be utilized keeping in mind the soil health benefits. Also, maintenance of sugarcane production under intensive cropping requires that organic carhon content of the soil must be retained either by the recycling of organic farm wastes or by the use of organic sources. Growing of green manure in the inter row spacing and incorporation at appropriate time not only supplement the fertilizer but also maintain the soil fertility and sustain the cane yield. Findings of different authors confirm that there is saving of $\mathrm{N}$ upto $25 \%$ when green manures were raised as intercrop in sugarcane. Inoculation of biofertilizers like Azospirillum, Azotobacter, Glucoacetobacter, Bacillus, Pseudomonas and Aspergillus improves the nitrogen and phosphorus content of soil and leads to a saving of $20-25 \%$ of inorganic fertilizers. It leads to $20-50 \%$ economy in fertilizer nutrients besides soil sustainability. A judicious conjugation of organic and inorganic sources in addition to biofertilizers is a prospective tool for maintaining the cane productivity as well as improving soil fertility in sugarcane and sugarcane based cropping systems.

\section{References}

Bhanuvally, M., Ramesha, Y.M. and Yogeeshappa, H. (2017). Nutrient uptake and millable cane yield of sugarcane as influenced by application of slow releasing nitrogen fertilizers. International Journal of Current Microbiology and Applied Sciences. 6(10): 855-862.

Bokhtiar, S.M., Paul, G.C., Rashid, M.A. and Rahman, A.B.M. (2001). Effect of press mud and inorganic nitrogen on soil fertility and yield of sugarcane grown in high Ganges riverflood plain soils of Bangladesh. Indian Sugar. 51: 235-241.

Chandra, R. Rana, N.S. Kumar, S. and Panwar, G.S. (2008). Effects of sugarcane residue and green manure practices in sugarcane-ratoon-wheat 
sequence on productivity, soil fertility and soil biological properties. Archives of Agronomy and Soil Science. 54(6): 651-664.

Durai, R. and Devaraj, G. (2003). Organic farming in sugarcane. Cooperative Sugar. 34(6): 491-492.

Hari, K. and Srinivasan, T.R. (2005). Response of sugarcane varieties to application of nitrogen fixing bacteria under different nitrogen levels. Sugar Tech. 7(2\&3): 28-31.

Jamuna, E. and Panneerselvam, R. (2014). Studies on the soil nutrient dynamics and PGPR population in sugarcane cultivated soil supplemented with bioinoculants and its effect on yield parameters. In : Proc. of the Natl. Sem. on Recent Advances and Challenges in Sugarcane Research, 23-24 January, Mysore, India. p.78.

Jeyaramana, S. and Alagudurai, S. (2003). Nitrogen and phosphorus management with green manureas intercrop and phosphobacteria incorporation in sugarcane. Indian Sugar. 52(10): 839842.

Jha, C.K., Sinha, S.K. and Thakur, S.K. (2017). Enhancing soil fertility, nutrient uptake and sugarcane productivity through integrated use of $\mathrm{Fe}$ and organics in sub-tropical system. Indian Journal of Ecology. 44(5): 521-525.

Kanjana, D. and Pitchai, J.G. (2009). Effect of organic, inorganic and biofertilizer on yield and yield attributing characteristics of sugarcane Co 86032. Indian Sugar. 59: 57-60.

Kathiresan, G. (2004). A review on use of biofertilizers on sugarcane production. Cooperative Sugar. 35(8): 631-638.

Kathiresan, G. and Manoharan, M.L. (1999). Efficiency of some organic manure on cane and sugar yield. Madras Agriculture Journal. 86(7/9): 426-428.

Kathiresan, G., Rengaraju, G., Manickam, G.,
Chinnasamy, K. and Ayyamperumal, A. (1993). Nitrogen economization for sugarcane through different sources of nitrogen. Cooperative Sugar. 24(7): 321-323.

Kumar, S., Chand, G., Mandal, D., Kumar, A. and Kumar, S. (2015). Effect of trash mulching on quantitative and qualitative parameters of sugarcane. Ecology, Environment and Conservation. 21: AS141-AS143.

Lakshmi, C.S.R., Sreelatha, T., Rani, T.U., Rao, S.R.K. and Naidu, N.V. (2011). Effect of organic manures on soil fertility and productivity of sugarcane in north-coastal zone of Andhra Pradesh. Indian Journal of Agricultural Research. 45(4): 307-313.

Lokhande, S.B. and Ghatge, R.D. (2001). Role of biofertilizers in integrated nutrient management in sugarcane. Proc, 50th Ann. Conv. D.S.T.A., Pune. pp. 102-111.

Manickam, G., Loganathan, S., Rajamanickam, B. and Sridhar, P. (2002). Studies on the effect of insitu incorporation of intercropped green manure on yield and quality of sugarcane (Sachcharum officinarum) under irrigated conditions. Res. Crops. 3(3): $506-508$.

Navale, A.M., Shinde, D.B., Vaidya, B.R. and Jadhav, S.B. (1995). Effect of Azotobacter and Azospirillum inoculation under graded levels of nitrogen on growth and yield of sugarcane (Saccharum officinarum). Indian Journal of Agronomy. 40(4): 665-669.

Patel, C.L. (2002). Integrated nutrient management in sugarcane based cropping system. Presented in state level seminar on "Integrated Nutrient Management in Rice-Sugarcane based Cropping Sequences" held on 19th August, 2002 at GAU, Navsari. pp: 19- 
30.

Paul, G.C. and Mannan, M.A. (2007). An integrated nutrient management approach to improve sugar productivity. Sugar Tech. 9(1): 28-35.

Rani, T.U., Rao, K.P. and Shakespear, P. (2011). Effect of integrated nitrogen management on yield and quality of plant crop and successive first and second ratoon crops of sugarcane. Cooperative Sugar. 42(12): 29-38.

Roodagi, L.I., Itnal, C.J. and Kandagave, R.B. (2000). Influence of planting system and intercrops on sugarcane tillering and yield. Indian Sugar. 50: 605-609.

Saini, S.K., Rajesh, A., Singh, V. and Sinha, S.K. (2006). Effect of fly ash, press mud cake and phosphorus solubilising bacteria (PSB) on yield, growth and quality of sugarcane. Indian Sugar. 56: 25-28.

Santhy, P., Shankar, J.S., Muthuvel, P. and Selvi, D. (1998). Long term fertilizer experiment status of $\mathrm{N}, \mathrm{P}$ and $\mathrm{K}$ fractions in soil. Journal of the Indian Society of Soil Science.4: 395-398.

Shankaraiah, C. and Hunsigi, G. (2000). Effect of associative nitrogen fixing and phosphate solubilising bioagents on growth, yield and quality of sugarcane. Tropical Agricultural Research. 12: 163-176.

Shankaraiah, C. and Kalyanamurthy, K.N. (2005). Effect of enriched press mud cake on growth, yield and quality of sugarcane. Sugar Tech. 7(2\&3): 1-4.

Shankaraiah, C. and Nagaraju, M.S. (2002). Economical and ecofriendly practices for sustainable sugarcane. Cooperative Sugar. 33(8): 647-653.

Shankaraiah, C., Nagaraju, M.S. and Hunsigi, G. (2001). Field evaluation of some promising associative nitrogen fixing bio-agents under graded levels of nitrogen for yield and quality of jaggery. Cooperative Sugar. 33(3): 39-
43.

Sharma, B.L., Singh, S., VedPrakash., Mishra, A.K., Srivatava, P.N., Singh, D.N. and Singh, S.B. (2005). Integrated nutrient management in sugarcane: Performance of FYM, Biocompost and press mud cake with inorganic $\mathrm{N}$ on growth and quality indices. Cooperative Sugar. 36(12): 993- 998.

Singh, A., Kumar, R. and Ram, B. (2014). Response of soil test based integrated nutrient management under sugarcane cultivation (CCP). In: Proc. of the Natl.

Sem. on Recent Advances and Challenges in Sugarcane Research, 2324 January, Mysore, India. p.71.

Singh, K.P., Suman, S., Singh, K.P., Suman, A., Singh, P.N. and Srivastava, T.K. (2007). Improving quality of sugarcane growing soils by organic amendments under Subtropical Climatic conditions of India. Biology and Fertility of. Soils. 44(2): 367-376.

Sinha, S.K, Jha, C.K., Kumar, V. and Pandey, S.S. (2017). Yield and soil organic carbon pool in relation to soil fertility of sugarcane (Saccharum species hybrid complex) plant-ratoon system under integrated nutrient management. Indian Journal of Agronomy. 62(1): 25-30.

Sinha, S.K., Jha, C.K. Kumar, V., Kumari, G. and Alam, M.(2014). Integrated effect of bio-methanated distillery effluent and bio-compost on soil properties, juice quality and yield of sugarcane in Entisol. SugarTech. 16(1): 75-79.

Sinha, S.K., Jha, C.K. Kumar, V., Kumari, G. and Alam, M.(2014). Integrated effect of bio-methanated distillery effluent and bio-compost on soil properties, juice quality and yield of sugarcane in Entisol. SugarTech. 16(1): 75-79.

Sonawane, D.A. and Sabale, R.N. (2000). Effect of different sources of organic nitrogen on growth, yield and quality of Suru sugarcane. Journal of 
Maharashtra Agriculture University. 25(1): 15-17.

Srivastava, T.K., Singh, K.P., Menhilal, Suman, A. and Kumar, P. (2008). Productivity and profitability of sugarcane (Saccharum spp. complex hybrid) in relation to organic nutrition under different cropping systems. Indian Journal of Agronomy. 53(4): 310-330.

Srivastava, T.K., Singh, K.P., Singh, P., Suman, A., Singh, S.R., Verma, R.R., Singh, V.K. and Singh, R.K. (2018). Effect of bio-manures on soil quality, cane productivity and soil carbon sequestration under long-term sugarcane (Saccharum officinarum) plant - ratoon system in Indian subtropics. Indian Journal of Agricultural Sciences. 88(11): 1696-1703.

Suman, A., Gaur, A., Shrivastava, A.K. and Yadav, R.L. (2005). Improving sugarcane growth and nutrient uptake by inoculating Gluconacetobacter diazotrophicus. Plant Growth Regulation. 47: 155-162.

Thakur, S.K., Jha, C.K., Alam, M. and Singh, V.P. (2012). Productivity, quality and soil fertility of sugarcane (Saccharum spp complex hybrid) plant and ratoon grown under organic and conventional farming system. Indian Journal of Agricultural Sciences. 82(10): 896-899.

Umesh, U.N., Kumar, V., Alam, M., Sinha, S.K. and Verma, K. (2013). Integrated effect of organic and inorganic fertilizers on yield, quality parameter and nutrient availability of sugarcane in calcareous soil. Sugar Tech. 15(4): 365369.

Umesh, U.N., Prasad, R.K. and Kumar, V. (2018). Integrated effect of organic and inorganic fertilizers on yield, quality parameter and nutrient availability of sugarcane in calcareous soil. Journal of Pharmacognosy and Phytochemistry. SP1: 556-560.

Vedprakash, Mangey Ram and Lal, K. (2009). Effect of continuous application of organic manure and inorganic fertilizers on yield and quality attributes of sugarcane. Cooperative Sugar. 40(7): 65-67.

Venkatakrishnan, D. and Ravichandran, M. (2007). Effect of organic manures and fly ash on nutrient uptake of sugarcane. Indian Sugar, 57: 41-46.

Venkatesh, D. and $M$ Venkateshwarlu. (2017). An Overview of the Indian Sugar Industry. BIMS International Journal of Social Science Research. : 11-16.

Virdia, H.M., Patel, C.L. and Patel, D.U. (2009). Integrated nutrient management for sugarcane (Saccharum spp. Hybrid complex) plant ratoon system. Indian Sugar. 59: 35-42.

Yadahalli, K.B. (2008). Influence of organic amendments on Sugarcane set rot development. International Journal of Plant Science. 3(2): 556-557.

\section{How to cite this article:}

Abhishek Ranjan, C. K. Jha and Navnit Kumar. 2020. A Review on Effect of INM on Sugarcane Growth, Yield and Quality. Int.J.Curr.Microbiol.App.Sci. 9(01): 2597-2605. doi: https://doi.org/10.20546/ijcmas.2020.901.294 